\title{
DISCOURSING WOMEN'S POLITICAL PARTICIPATION TOWARDS ACHIEVING SUSTAINABLE DEVELOPMENT: THE CASE OF WOMEN IN PARTI ISLAM SE-MALAYSIA (PAS)
}

\section{Zaireeni Azmi}

Centre for Research on Women and Gender (KANITA), Universiti Sains Malaysia, Pulau Pinang, MALAYSIA

Email: zaireeni_azmi@usm.my

Published online: 15 April 2020

To cite this article: Zaireeni Azmi. 2020. Discoursing women's political participation towards achieving sustainable development: The case of women in Parti Islam Se-Malaysia (PAS). Kajian Malaysia 38(Supp.1): 67-88. https://doi.org/10.21315/km2020.38.s1.5

To link to this article: $\mathrm{https}: / /$ doi.org/10.21315/km2020.38.s 1.5

\section{ABSTRACT}

Malaysia has been committed to meet its commitments to the Sustainable Development Goals (SDGs) by 2030. One of the goals is to achieve gender equality. However, in Malaysia, the Global Gender Gap Index which measures gender disparities in economic participation and opportunities, education attainment, health and political empowerment reported that Malaysia ranked at 111 out of 145 countries in 2016. It has fallen far from its overall ranking of 72 in 2006. In terms of political participation, the low score in politics is because of the lack of women in leadership and decision-making positions that dragged down Malaysia's index even though Malaysia had set a target for women to fill $30 \%$ or more in decision-making positions. In the recent 14 th general election, a total of 252 female candidates named out of the 2,333 parliament and state seats resulted in only 92 female elected representatives. This article provides an overview of women's political participation focusing on members of Parti Islam Se-Malaysia (PAS). There were 30 female respondents interviewed and they were recruited from the two states in Malaysia namely Selangor and Kelantan. It analyses the reasons for women's missing presence at the decision-making level in the party and at national level which contributed to Malaysia's slow achievement of the SDGs. This article will discuss how PAS's organisational structure and women's preference will impose challenges towards 
achieving SDG 5. Women themselves determine the level of participation and contributions that they are willing to play in politics.

Keywords: women, Muslimat, political participation, Parti Islam Se-Malaysia (PAS)

\section{INTRODUCTION}

In 2016, the motto "Leave No One Behind" is a central commitment of Sustainable Development Goals (SDGs) to promote social, economic and environmental development (Kim 2017) and to include marginalised people to be involved in and benefited by progress. One of the SDGs indicators is to achieve gender equality and empower all women and girls by 2030. The SDGs will only be realised if both men and women are given equal chances and opportunities to participate as recipients and decision makers of the development of their countries. The SDG 5 (gender equality), particularly addresses the fields where countries have failed to meet their gender-equality obligations (Dhar 2018). It is important to provide full and equal access for women in order to improve their status and well-being at every level of social and economic arena especially at the decision-making level. The discussion in this article will focus on gender equality sub-goal 5.5 which looks into women's participation in politics. The Global Gender Gap Report of the World Economic Forum reads that gender parity is a long way to be achieved if women are continuously denied political power at the decision-making level (World Economic Forum 2017). Participation in politics at all levels is a vital component of sustainable development. The involvement of women in political activities is important because it will contribute to the process of sustainable development, therefore improving the capacities, competencies and potentials of society. However, women's voices and presence are still missing from leadership positions including the executive branches of governments and parliaments worldwide, which resulted in slowing down realisation efforts of SDGs.

Political participation has been defined by different scholars which include governance, activities conducted to influence structure, policies and the authorities of government or in a hierarchical manner starting from as simple an action as voting, attending political rallies, being active party members and holding offices (Milbrath 1971; Verba, Scholzman and Brady 1995). There are a number of studies done to explore and investigate issues related to the political participation of women in leadership and elected positions examining gender inequality (Paxton, Kunovich and Hughes 2007; Seyedeh, Hasnita and Hossein 2010; Douglas 2014; 
Kassa 2015; Cowper-Smith et al. 2017). In the Malaysian context, many scholars have looked into women's political participation and listed factors that challenged their participation especially at the decision-making level including religio-cultural factors (Tan 1993; Salbiah 1994; Jamilah 1995; Sharifah Syahirah and Norfarhanis 2015), as well as political structures, limited sources (human capital and finances) and lack of self-confidence (Rashila 1998). On top of that, there are findings that assert that despite the structural and political barriers, other personal factors do motivate successful women leaders. These leaders believe in themselves and are committed, passionate and interested to become one (Zeenath 2006; Munira 2004). The discourse of women's political participation in Malaysia should also consider women's own political ambitions that may influence their levels of participation. The question of why the number of women is still low should reflect what the women actually want in politics and how they perceive their role in this domain.

Malaysia is keen to support and implement the 2030 Agenda for Sustainable Development and its 17 SDGs have been formulated with the people at the centre of all development efforts as reflected in the Eleventh Malaysia Plan. The country has been consistent in its endeavours to encourage women's and girls' rights. The Plan of Action for the Advancement of Women (2010-2015) was also formulated to further integrate women in development and advance their status in society. Malaysia's national policies are consistent with international legal instruments on gender equality, including the Convention on the Elimination of All Forms of Discrimination against Women (CEDAW) which the country has ratified.

Nevertheless, although Article 8(2) in the Constitution was amended in 2001 to guarantee equality and non-discrimination on the basis of gender, gender equality in Malaysia remains critical. The Global Gender Gap Index which measures gender disparities in economic opportunities, education, health and politics reported that Malaysia ranked at 111 out of 145 countries following a score of 0.655 in 2016 which is far from its overall ranking of 72 in 2006. The country is also ranked at 132 out of 145 countries in the ranking for women in ministerial positions. The low score in politics is because of lack of women in leadership and decision-making positions which dragged down Malaysia's index. They are less likely to occupy executive branch posts or key cabinet positions even though Malaysia has set a target for women to fill at least $30 \%$ or more of the decision-making positions. In the recent 14th general election, a total of 252 female candidates were elected out of the 2,333 candidates for parliament and state seats. Women Members of Parliament (MPs) and State Legislative Assembly members (Ahli Dewan Undangan Negeri, ADUN) now represent only $14.4 \%$ of all MPs and ADUN, a high record. Women MPs elected in 2018 included 10 Barisan Nasional MPs, 19 Pakatan Harapan MPs and one MP each from Parti Islam Se-Malaysia (PAS) and Parti Warisan (Warisan) (Table 1). 


\section{Zaireeni Azmi}

Table 1: Women candidates by political party in 2018

\begin{tabular}{|c|c|c|}
\hline Political party & Female candidates & Winners \\
\hline \multicolumn{3}{|l|}{ Barisan Nasional (BN) } \\
\hline $\mathrm{UMNO} / \mathrm{BN}$ & 65 & 31 \\
\hline MCA & 17 & 0 \\
\hline MIC & 4 & 0 \\
\hline \multicolumn{3}{|l|}{ Pakatan Harapan } \\
\hline DAP & 28 & 28 \\
\hline AMANAH & 10 & 3 \\
\hline BERSATU & 6 & 2 \\
\hline PKR & 41 & 21 \\
\hline PAS & 38 & 4 \\
\hline \multicolumn{3}{|l|}{ Other parties } \\
\hline PRM & 5 & 0 \\
\hline Bebas (Independent) & 2 & 0 \\
\hline PSM & 3 & 0 \\
\hline PFP & 2 & 0 \\
\hline HARAPAN RAKYAT & 9 & 0 \\
\hline PCS & 2 & 0 \\
\hline WARISAN & 9 & 3 \\
\hline PKS & 2 & 0 \\
\hline MU & 4 & 0 \\
\hline PAP & 2 & 0 \\
\hline PEACE & 1 & 0 \\
\hline PPRS & 1 & 0 \\
\hline Total & 251 & 92 \\
\hline
\end{tabular}

Note: Please refer Appendix for political party in full name.

From the data provided by Tables 1 and 2, it is clear that not only is women's representation in politics low, but their numbers are also small in other decisionmaking bodies and its due processes. However, the judiciary looks to be an exception, because the number of women's representation is higher - more than $30 \%$ compared to the other branches of government. Despite Wan Azizah Wan Ismail being appointed as the first female Deputy Prime Minister, the federal cabinet consists only of five full women ministers and four deputy ministers, representing $18 \%$ women out of 50 members. At the state level, only one woman was appointed as a state executive councillor in every state, except three in Kedah and Perlis each, and two in Selangor. Previously without a female elected 
representative, Terengganu recently got its first female senator, appointed by the PAS-led government. On the whole, Malaysia still lags behind in the numbers of women decision makers in politics.

Table 2: Women in other decision-making bodies

\begin{tabular}{lcc}
\hline Decision-making bodies & $\begin{array}{c}\text { Number of } \\
\text { women }\end{array}$ & $\begin{array}{c}\text { Percentage of } \\
\text { women }\end{array}$ \\
\hline Executive (cabinet ministers and deputy ministers)* & 9 & 18 \\
Members of house representative* & 92 & 14.4 \\
Senators* & 13 & 19 \\
Secretary general, deputy secretary general, director general, & 42 & 18.1 \\
director and general manager of statutory bodies** & & \\
Top management in public sector** & 34 & 35.6 \\
Syariah' judiciary** & 62 & 26.1 \\
Civil judiciary** & 54 & 38.3 \\
Members of board in banking sector by sex** & 78 & 11.5 \\
Member of board of directors in companies related to & 111 & 14.1 \\
Ministry of Finance (incorporated) $* *$ & & \\
\hline
\end{tabular}

Note: * Parliament Malaysia (2018); ${ }^{* *}$ KPWKM (2016)

Malaysian history has positioned the significant roles of women in politics as campaign workers, voters, party supporters and community leaders. The role of women in the country's politics has been narrated in Malay historical documents such as Sejarah Melayu (Malay Annals), Bustan al-Salatin and Hikayat Seri Kelantan, all showing their involvement in national politics of their times (Zaireeni 2001). Even Malay customs and traditions according to Wazir Jahan (1992) freed Malay women and gave them the freedom to speak and act. This is also acknowledged by Rudie (1994), who claims that Kelantanese women were more likely to play a significant role in the affairs of society, especially in the economic sphere whether by owning, buying or selling land, engaging in agricultural production activities and dominating businesses in markets. The women have been involved in political domains directly or indirectly before independence through the establishment of political parties that fought for independence. Thus, the existence of women cannot only be measured based on the numbers being appointed at the party leadership level and national politics or elections. The involvement of women in social and political domains reveals their presence in local and national politics, especially the active role of mobilising community support which ensures the continuity of key political parties in Malaysia. Although the number of women who were appointed as leaders in the organisational structure of political parties was not 
large at that time, their involvements and existence were very significant to the country's politics. Furthermore, half of the membership of the existing political parties such as United Malays National Organisation (UMNO), PAS and Parti Keadilan Rakyat (PKR) comprise women. Since independence, women have played a meaningful and substantial role to ensure the survival of their respective political parties by supporting party aspirations through political activities, supporting party leadership decisions and seeking, registering and recruiting new members through various social and religious activities other than being an active party worker during the elections to secure votes.

It is imperative to understand why the gender gap in political empowerment in Malaysia is wide and perhaps a reason the country may not be able to achieve gender equality. Although women in Malaysia have significantly and actively been involved in political activities, the gender gap continues to exist in terms of their representation at the leadership level. The gender gap in political representation is remarkably apparent in terms of candidates for parliamentary and state assembly seats as well as top leadership positions at the party's structure. The standard measurement of women's political participation looks at the proportion of seats held by women in national parliaments and recently in local government. It has been instrumental in indicating that women's participation in politics is one of the areas of gender inequality (United Nations Statistics Division 2016). Dariko et al. (2017) did a gender assessment focusing on the division of labour between women and men and analysing access, power and control over resources. They evaluated existing political bodies and structure by examining women's representatives in national parliaments and local governments and proportion of women in managerial positions to indicate whether SDGs have been implemented and have taken place in Georgia. Using women in PAS as a case study, this article will try to explore women's perspective regarding their role in politics and how it impacts SDGs which will be the centre of this article's discussion.

\section{METHODOLOGY}

This study adopts a feminist approach which believes each study will not be free from the researcher's own views and values as the researchers themselves are constructed by their own social experience (Brooks and Hesse-Biber 2007). The assertion in the feminist study approach is also to ensure that the voice and experience of the informants (women) are addressed (Kitzinger 2007) and as a way to get more accurate and complete information about the lived reality of women (Maynard 2004). The use of narrative in writing is a method of adherence to a feminist approach in presenting women's voices in the study's findings. 
It is important that in a study, informants are given full space so that the interview process becomes an experience that empowers them (Puwar 1997). Therefore, researchers must be sensitive to the needs and comfort of informants during the interview process.

The qualitative method is used for collecting data as it will provide easy access to the women's voices that are marginalised and oppressed in society (Brooks and Hesse-Biber 2007). Purposive sampling was applied, and the informants' qualifications were based on their experiences, expertise and knowledge on the research topics. Data from this study came mainly from narrative interviews with 30 informants from Kelantan and Selangor. These two states were essentially chosen because both states were governed by PAS, the former fully and the latter partly as a member of the ruling coalition. Both states are seen as appropriate to study the Muslimat's ${ }^{1}$ position in politics be it at the party's structure and national level.

This study applied the narrative interview that would be able to produce storied accounts that could explore informants' experiences (Schultz 1961; Bauer 1996). The narrative interview helps informants to be reflexive during the interview and narrate their stories in their own everyday language.

All interviews were copied in verbatim by the researcher. The process of listening and transcribing was done repeatedly as it helped the researcher to understand and interpret the data. Themes have been developed according to transcripts based on similarities and differences, repetitions and frequencies of references to certain words, experiences, views, expressions and emotions disclosed by informants in their narratives. The feminist approach emphasises the importance of informal voices being represented. Thus, statements from informants are quoted directly in writing.

All of the informants are PAS members and hold a position either as MPs, ADUN, local councillors as well as top leaders at the party's organisational structure. These women's experiences, beliefs and attitudes towards their political participation would provide an answer to future Malaysian achievements in fulfilling SDGs.

\section{THE ORGANISATIONAL STRUCTURE OF WOMEN IN PAS}

PAS established its women's wing on 3 January 1953 during the first annual general meeting of PAS in Kepala Batas, known as Dewan Muslimat PAS Malaysia (DMPM). The formalisation of women members in this wing was a wise move to promote PAS's Islamic political ideology. Their main objective is "to unite Muslim women in the country, to widen the influence of PAS through Muslimat activities while shaping their personality to be Muslims who are responsible to the religion 
and the nation, and to persuade them to the ideals of Islam championed by PAS" (Ng, Maznah and Tan 2006). From the beginning, DMPM has played a significant role in recruiting Muslim women to join and secure electoral success for the party. There are three other "dewan" that have an equal status in the organisational hierarchy, namely Dewan Ulamak or the Religious Scholarly Wing, Dewan Pemuda or the Youth Wing and Dewan Himpunan Penyokong PAS (DHPP) for non-Muslim supporters. According to the party's constitution, it provides the same opportunities for women and men to participate in the party leadership at all levels either in the Council of Syura Ulamak (Majlis Syura Ulamak, MSU), the PAS Central Working Committee (Jawatankuasa Kerja PAS Pusat, JKKPP) and the PAS General Assembly (Muktamar).

In PAS's organisational structure, the Muktamar is the place where top leaders are elected once every two years. In the context of democracy, the Muktamar is seen to provide space, opportunity and empower PAS members to choose leaders, to voice out their opinion and take part in the decision-making process on the direction and long-term goals of the party. According to the PAS constitution 2011 amendment, the delegates in the Muktamar should consist of the president and the deputy, members of the MSU and members of JKKPP, PAS's state and federal territories commissioners. In addition, Yang Dipertua PAS Kawasan (district), no fewer than 4 people and not more than 10 representatives are appointed by every district, 20 representatives from and appointed by the PAS Ulamak Wing (Dewan Ulamak PAS Pusat, DUPP), 20 representatives from and appointed by the PAS Youth Wing (Dewan Pemuda PAS Pusat, DPPP), and 20 representatives from and appointed by the DMPM congress (Parti Islam SeMalaysia 2012, Clause 16[2]). The number of representatives or delegates at the Muktamar depends on the number of delegates from the district. Muslimat have the opportunity to be part of the party's delegation and leadership in the DMPM, the JKKPP, the party's top leadership, the MSU, the state commissioner, the Yang Dipertua PAS Kawasan and representatives from DUPP through appointment and election. But the party's practices and culture tend to choose and appoint men to fill leadership seats thus limiting Muslimat's involvement at decision-making levels. The election of the party leaders was made through the vote casts by delegates during the Muktamar but the number of women's delegates is much lower than men. In 2018 there were 106 female delegates to the PAS General Assembly from 1,092 total delegates, a mere $9.7 \%$. Although the number of PAS's districts is increasing and the 2011 amendment of the constitution allows more representatives to be elected from the districts, but regional-level leaders tend to send men's representatives. Muslimat's representatives in JKKPP have never exceeded four people out of 38 members. Salmah Sheikh Hussein was the first woman to be elected in JKKPP for five consecutive sessions, from 1966 until the 1979-1981 sessions (Husam 2013). She 
was re-elected for the 1981-1983 sessions and became the only woman against 21 other PAS Central Working Committee Member (Ahli Jawatankuasa Kerja PAS Pusat, AJKPP) (Aiman Athirah 2006). After 1983, only the chief of DMPM would be representing the women in JKKPP. Then in 1999, Dr. Lo' Lo' was appointed before the delegation elected her in 2001 to be in the committee. In the same year, four other Muslimat also offered to contest and competed with men. Statistics on women candidates for the JKKPP showed that there were 8 women candidates from all 34 candidates in 2007 and only 10 women contesting out of 86 candidates in 2009. In 2011, 8 women were nominated from a total of 53 candidates but only 2 were selected. In 2013, there were 12 women candidates compared to 97 candidates in total. In 2015, 7 women competed with 47 other male candidates. All 3 nominated women for JKKPP won for the 2017-2019 term against 26 male candidates. Although the number of women who volunteered and were nominated to contest increased but those chosen by the delegates were still small. The lack of women at the party's top leadership would hinder their visibility in political realms and will indirectly promote only male leadership. Besides, many of PAS's top leaders were born out of the Dewan Ulamak and Dewan Pemuda. Prior to 2009, Muslimat were only been represented by DMPM at the Muktamar. Since the opening of space for women, the Syura Council which is the highest, influential and most powerful institution within PAS has only two women at a time as members. Numbers of Muslimat selected by members at the district branch to be delegates of Muktamar also remain small.

Without a doubt the DMPM's functions, forms and goals were created to support PAS's ideology and this is clearly stressed by delegates during the Muktamar in Terengganu in 2018. In a society that adheres to customs and religions in accordance with the interpretation of men, religion applies to women to make them passive political actors and to give space to men to dominate (Fatima 2013). Muslimat identified their beliefs with PAS's ideology and objective. PAS's stand in regard to Islam and politics and its strong approach of combining Islamic practice in administration and daily life is closely related and embraced by the women. The significant role of Muslimat as party supporters have been mentioned in the existing literature and they are depicted as compliant, loyal, devoted and act in accordance with the dominion of male party leaders (Dancz 1987; Maznah 2001). Over the course of their participation, Muslimat has been active in reaching out to the community through various religious and welfare activities. Their involvement is positioned on helping to spread Islamic teaching and to extend PAS's positive image and influence in society through community everyday activities especially providing religious programmes which include classes and talks; as well as providing assistance during disasters, listening to people's problems and trying to channel those who can help, home visits from time to time; and specifically 
to cater for the party by collecting donations, electoral campaign tasks and many more activities. Although Muslimat has already proven that they are committed, hardworking and competent members of PAS but only handful of them are elected, appointed or selected to be at the decision-making level either in the organisational hierarchical structure and at the state level (in PAS's ruling states). The scenario leaves a gap for women's presence are still missing at the decision-making level in the party and at national level which contributed to Malaysia's slow achievement of the SDGs. One simple explanation could be the patriarchal structure embedded within the internal party structure and policies as well as societal gender barriers. These have been highlighted in some literature (Rashila 1998; Maznah 2001). Nevertheless, because women are not passive actors in the political realm, their own understandings and perspectives regarding their significant role in politics may differ from the need to be represented equally at leadership levels in economic, political and social aspects of life. Their stand would provide an explanation for the low numbers of women at the leadership and decision-making level in politics and hindering gender equality in the sustainable development of Malaysia.

\section{RESULTS}

The majority of the informants are between 40 and 60 years old. Based on the age category of informants it can be concluded that Muslimat at the decisionmaking level represents women of various age groups and DMPM becomes PAS's liaison to women of all generations. In addition, the age range among informants shows the extent of the data obtained. Informants also feature diverse educational backgrounds and professions. The majority of informants have at least a university degree with four people with a bachelor's degree, two doctorate holders and five other diploma graduates. One informant did not finish her studies at university and the another two received education from religious schools or sekolah pondok. In terms of the profession, 10 informants are educators (five religious teachers, three ordinary teachers and two lecturers). Eight people are from professional backgrounds such as medical doctors, law practitioners and engineers, four involved in business and eight others are semi-professional and party activists. Informants' experience in their respective jobs provides them with the skills and knowledge to heed the organisation. It helps in managing structural and cultural changes within the party. The findings show that there is a significant relation between the status of employment and with their involvements in politics. Their professional and involvement with other organisations enhanced their skills, self-esteem and financial standing that is very useful politically. It also facilitates them to position themselves at decision-making levels. 
All informants were married and had children except for two. Marital status does not prevent informants from being fully active in political activities. There are 16 informants who have at least four children and eight others have between five to nine children. Interestingly, there are informants who have more than 10 children. Three of them are DMPM's top leaders, ever nominated in the elections and elected MPs. The study found that all informants were active in partisan politics when their children were small. Despite having a large number of children, informants engage in political activities and some of them assume responsibility as leaders at various party levels.

Informants' narratives illustrate that family and children are not factors that hinder them from being committed to party work and activities. Although some of them bore a large number of children, the support from their husband and other family members motivate them to be active members. This finding supports Fox and Lawless's (2014) assertion that family management does not stave off women's political involvement, especially those with political potential and ambitions. But at the same time, it does not mean that they are free from the burden of the traditional role of women. Informants have adapted to conditions that require them to balance the needs of their families and political career as Lawless (2014) claims, "the work/life balance has become such a regular part of their daily routine that women's family dynamics do not discourage them from thinking about or embarking on a political career" (p. 8).

According to one of the informants that has 12 children and are holding several leadership positions both at national and state level:

When [my] child was small and [I had to] go to KL to attend the programme, I tied the little one on the shoulder, [at that time when] the kids were small. [I] Put the child over the arm, [cover] and twist with sarong, then drove the car to the programme because no one was [available] to hold [the child]. If [the child] is placed underneath the seat, the kid will thrash around and there were her sisters so it will be difficult. So, the sister would sit in the passenger seat, the small child being tied up with a sarong, protected with and [I] drove. [I] went down [to visit branches], never missed visiting branches even during the fasting month. I will conduct tadarus [reciting Quran] for each branch. I was really active. [I] brought them together to KL because I have no maid whether in Kelantan or KL. And I have no driver. I do everything myself.

So, thanks to Allah, with 12 children, none of them caused me to put aside my commitment to the party. Until now with nine grandchildren I am still active. Thanks to Allah. 
Although the role of a mother and a wife are not factoring that restrict their political participation, there is the need to balance the role as a good mother, wife and politician. As narrated by one of the informants who was active in PAS when she was in college and has four children:

We are not troubled [by these roles], not fundamentally, although, these roles are not the basic responsibility and obligation of a wife. We know household chores are not our basic obligation or our service to our husband, to manage the household chores. It is different from men in which it will be easier for them [to be active in politics] because ... Because we, women by default, we know for sure that although it is not our main responsibility [to manage the household] but we have to do them because we want to help our husband. So, it becomes a routine work.

The informants believed that they can only fulfilled the role of politicians if they are supported by their husbands. Female politicians need to rely on good support systems in terms of childcare and household management when actively involved in politics. According to the informants, despite having to travel to meet with voters, attending parliamentary sessions and committee meetings held in the capital or outside of the residential area, it will not be an insurmountable challenge as long as they have the support from their parents, husbands, or other family members. It explains the reason why Muslimat actively involved in PAS despite the party's position as an opposition party that has limited and insufficient funds to execute most of its activities. Interestingly, women became members of PAS at different points of their lives. Some of them were exposed to PAS when they were young and started their journey in the party since high school. Others became actively involved when they were in university and the rest became active members after they got married or had a job. The narratives from these women also revealed that many of them had joined PAS in the 80s and early 90s. Informants from Selangor claimed that:

I started to become involved in campus politics and at the same time around 1987, I was also involved in political party activism and in PAS specifically...Coincidently I got married in 1987 and I lived in Ampang. Then I realised that maybe at that time PAS was not as popular as it is nowadays [thus not many people joined PAS] in 1987 or late 1987.

When I joined UM [University Malaya] I attended all the tamrin's programmes and in year two I submitted the form to join PAS. To be a PAS member. It was in 1982. PAS was just at the beginning of Kepimpinan Ulama. 
As a medical doctor, I was busy with medical stuff beside the clinic, with patients, and not really interested in formal politics. But since students' days I have been following the political situation, I studied in Australia. I follow what's happening in Malaysia. We see things that happen, the system, the problem which is not right. So, I started to become a PAS member in 1990 but as an ordinary member.

The narratives quoted above are among the many narratives from which it can be concluded that educated and professional women joined PAS long before Reformasi ${ }^{2}$ in 1999 . They were not visibly seen as they preferred to play a behindthe-scenes role as well as to cover their positions as civil servants. Some of them even had to use fake names once chosen to be on the DMPM leadership structure. Prior to 14th General Election, there were some well-known female figures who chose to wear a niqab $b^{3}$ during Muslimat's general assemblies to hide their identity. Only when the Reformasi got off the ground did they openly show their support to PAS. In terms of sustaining women support, it seems that PAS has been getting enormous support from grassroots and professionals and they are willing to play down their role for the benefit of the party.

\section{RESEARCH HIGHLIGHTS}

The SDG 5's aim is to achieve gender equality and to empower all women and girls. In the political arena, numbers of seats in national parliaments and local governments held by women are the indicator to determine women's equal access to key decision-making positions within formal political processes. PAS depends on women's wing in mobilising and gaining support from other women. Although the party has taken a more proactive step by highlighting women and raising their candidacies in the election, the process is very slow. The contribution of Muslimat is controlled and restricted to social work and not political tasks except during the elections. However, according to Muslimat, their involvement is not only in the context of political parties but covers all community activities designed as charitable work. This is manifested through the active participation and continuous participation of Muslimat in society. Informants rejected the indication that Muslimat are passive members. They have been continuously participating in community-based activities through various programmes at every level. One respondent emphasises on doing community in PAS as her main objective of joining the party.

I did not join politics as a way to get a position, to be recognised or not, no. But it is more than that. Even though we said that we are not given any position...not being appointed to the council, [but] I have been 
working for almost 24 years. Since the age of 18, I've been attending and undergoing usrah [religious class]. I am used to attending [party's] programmes. Organised programmes. I am used to it. This community work [helping out] has been a part of us.

Other narratives also highlighted that Muslimat do not stress on positions because they abide by the party culture that forbids members from demanding leadership posts. It is well known that those who ask for a position will not be entertained, and they will not be selected to fill leadership positions. The norm of not to ask for a position is part of PAS's culture and the value cultivation of a moral character in politics. Although it is debatable whether male members of PAS conform to it, Muslimat adhere to this norm and strongly believe that it is one of the indicators to choose a leader. One of the informants narrated that other women in PAS refused to hold leadership position because they were not ready to be a leader or commit themselves to the post:

It's just that they don't want to. They don't want to be involved [at the decision-making level]. "... it is enough at this level [middle level], Yb. We have enough". That's all. Not that they are not capable [to be leaders]

The disinclination of Muslimat to seek higher decision-making posts and demonstrate low political ambition gives a wrong signal of their capabilities and roles that they want to or can play in politics. Although their individual preferences are gendered and conservative but the majority of them are comfortable with this notion. This perspective shapes Muslimat's attitude to be loyal supporters and adhere to the male-dominated party leadership. Also, it can be translated as low gender awareness among informants. Clearly, within the democratic participation, Muslimat's involvement is shaped by cultural factors, norms and religious values that influence their choices in determining their political stance. Interestingly, all informants are active women at various levels who consciously do not place themselves as individuals who are interested in leadership positions. Despite recognising the importance of appointing and increasing the number of female leaders, they generally believe and claim that women's contributions are not limited to the leadership level alone.

According to Muslimat's narrations, they have been active members of the party's structure and society, not only as party workers but their role is also as the backbone of PAS's survival through the activities of strengthening the party and engaging community. The fact that their number as candidates is small helps immerse their significant roles in the party and politics at different levels. PAS as a missionary and political party is considered to meet the needs of some women who are more concerned to serve and contribute to the society at the grassroots than being a leader. 
This article highlights that women in PAS have a different conceptualisation of meaning and definition of political participation. The concept of visibility, power and position shall not be limited to formal political space alone. The importance of their role cannot only be measured based on the number being appointed at the party leadership level or party management and national politics or elections. The visibility of women in politics should also be assessed for more substantive participation and impact on the community which would also widen the meaning of participation in the context of democracy. Although the number of female representations at the decision-making stage is important as a benchmark for democratisation from a Western perspective, local history and culture have shown significant involvement of Malaysian women in informal politics. In addition, the women's willingness to be the backbone of the party succeeded in ensuring PAS's continued political presence.

However, the narratives informed that their visibility is also strongly influenced by the intangible element through participation in society and public acceptance of the role they play. The form of activities that focus on welfare and spirituality reinforce Muslimat's visibility in society. Furthermore, the approach that promotes inclusiveness of all members of society positions Muslimat's visibility and approachability. Muslimat become more accommodating towards both Muslim and non-Muslim communities and towards the promotion of democracy and transparency within the framework of Islam. The informants have high self-esteem and political desire to engage in politics. They do not see their absence at the highest level of party leadership or as election candidates as an end to their political career.

\section{MOVING TOWARDS SDGs?}

Malaysia is in the foreseeable position of $10.36 \%$ in the ASEAN region in terms of the number of female leaders. However, discussing women's visibility or the existence of women in the context of formal political representation alone is a form of discrimination that does not recognise the contributions and roles played by women in the wider political engagements. The concept of political engagement is not limited to voting or influencing decision-making only. It includes various other activities such as political party membership, election campaign, attending party meetings, demonstrations, communication with leaders, holding party posts, contesting in elections, membership in representative bodies and community activities.

In the context of democratisation, the party's constitution provides equal opportunities for members to be elected as leaders. At every level of organisational structure, there is a space accessible to Muslimat. In general, the 
party's constitution can be described as not opposing the presence of women in decision-making. Nevertheless, it does not openly express support for gender equality and women's rights. In fact, there are no mechanisms in the party constitution that can promote the visibility of women in the party structure. Muslimat's position within the party can be determined by many factors supporting, tolerating or opposing their visibility. The culture of the organisation such as the acceptance of women's presence as leaders among male leaders and determining who is eligible to be promoted as leaders play an important role in underscoring the extent of the role and the status of Muslimat in the party. Undoubtedly the highest leadership of PAS supports the presence of women at the leadership level, but it is constrained by social streams of gender and patronage practices. The political culture that empowers men and the lack of the opportunity and space for Muslimat to play a role at the decision-making stage tends to curb women's political development.

In addition, PAS does not have formal rules or quotas that promote gender equality. Although it did practice informal reservation of seats during 13th general election and tried to formalise numbers of women delegates from Dewan Ulamak Kawasan, it was never realised. Muslimat still had to fight for more seats during the election. As a result, out of 158 PAS candidates in 14th General Election, only $8.9 \%$ of them are women. This is still far behind the target to achieve at least $30 \%$ of women representatives. As for women delegates, they are more inclined to elect men as their representatives.

In the end, women themselves determine the level of participation and contributions that they are willing to play in politics. Islam is a self-identity that is a source of inspiration for their involvement in politics and PAS is used as a mechanism to contribute to society. Muslimat adhere to the organisational culture by not expressing the desire to take office or position even if they are qualified. They have chosen not to be keen to be leaders because of the PAS culture which does not appoint individuals requesting for a party post or as a candidate. However, they did not feel subordinated and acknowledged that they were doing their best for the party's interest. Or it can also mean that they think that they are less qualified than men to run for office. Despite the humble attitude or approach by Muslimat PAS which places them at a high moral standing, it can be argued that it is a form of subordination because they are merely party workers and submit to the power of the party's top leadership dominated by men. Women's position as party's supporters is often perceived as chained by patriarchal values that restricted their movement (Saba 2005). Saba (2005) claimed that Muslim women's agency should be seen in not only the usual forms and institutions of politics and from the Western secular feminist. Muslimat's narratives which illustrate their desire not to be party leaders and emphasise in working with grassroots is maybe the way women are telling their stories. 
Looking at the way Muslimat justify their presence and participation in politics, Malaysia may not be able to fulfil the sustainable development goal for gender equality in politics if drastic measures are not taken. The above case study illustrates how culture and individual preference intersect with patriarchy norms in undermining opportunities for more women to be at the decision-making level. It explains why there is a small number of women in politics or other organisational structure at the decision-making level which drags down Malaysia's index in the Global Gender Gap report and hinders the country's commitment towards SDGs. Thus, it is crucial for Malaysia to work on short-term and long-term strategies to encourage more women's representation in leadership positions. Some of the temporary measures worth to be explored include gender quota and other affirmative actions. What is more important is for the party to acknowledge the significance of having more women at the decision-making level and adapting its internal party quotas. Gender quota would enable the party to nominate a certain percentage of women in general elections (Bjarnegård and Zetterberg 2016). It will secure definite numbers of women representatives. Besides, the political party needs to institute the $30 \%$ minimum quota at all levels to push for women visibility as leaders. They need to be in the leadership positions and get involved in the process of strategising the direction, objective, agenda of the party as well as participating in strategic thinking about tactics and networking (Waylen 2014). It is also important to acknowledge that political culture and party system do play a part in supporting women's representation (O'Neil and Domingo 2015). If the party's culture and structure do not encourage women to be leaders, it will affect women's pool of talent. Thus, it is also crucial to set up and endow political apprenticeship. This can be achieved by institutionalising political education through various organisations namely schools, non-government organisations as well as political training by political parties. Nevertheless, Muslimat's narratives clearly provide another perspective within the local wisdom of defining political participation and representation, and how it impacts on SDGs. Thus, Malaysia should haves its own gender gap contexts that differ from the West's common variables.

\section{CONCLUSION}

This article is not a comparative study between the Muslimat in Selangor and Kelantan. It also does not represent the entire population of Malay women. Nonetheless it helps to understand why even though there have been numerous attempts to position women at decision-making levels such as the amendment of Article 8(2) of the Federal Constitution (2001), the Nineth Malaysia Plan which put at least $30 \%$ women at the decision-making level, the Millennium 
Development Goals Putrajaya Declaration, and Action Program on Women's Development in Countries of Non-Aligned Movement (NAM Putrajaya Declaration) and the National Women's Policy revised in 2009 which contains the Women's Development Action Plan, their numbers are still low.

\section{NOTES}

1. Muslimat is a term to refer to women in PAS and widely used after the leadership of the party was taken over by the new generation who claimed highlighting Islam's ambitions as outlined by the constitutions in accordance with the spirit of PAS and the Islamic movement in 1982.

2. Reformasi was a political reformation movement started in September 1998 after the former Deputy Prime Minister, Anwar Ibrahim was sacked by the Prime Minister of Malaysia.

3. Niqab is a garment of clothing that covers the face, worn by some Muslim women.

\section{ACKNOWLEDGEMENTS}

The source of the research finding for this article funded by Universiti Sains Malaysia through Academic Staff Higher Education Scheme (ASHES), 20132017. 


\section{APPENDIX}

\section{List of abbreviations: Political parties}

\begin{tabular}{ll}
\hline AMANAH & Parti Amanah Negara \\
BERSATU & Parti Pribumi Bersatu Malaysia or Malaysian United \\
Indigenous Party \\
DAP & Barisan Nasional \\
HARAPAN RAKYAT & Parti Tindakan Demokratik or Democratic Action Party \\
MCA & Parti Harapan Rakyat Sabah \\
MIC & Malaysian Chinese Association \\
MU & Malaysian Indian Congress \\
PAP & Malaysian United Indigenous Party \\
PAS & Parti Alternatif Rakyat or People's Alternative Party \\
PCS & Parti Islam Se-Malaysia \\
PFP & Parti Cinta Sabah \\
PEACE & Penang Front Party \\
PKN & Parti Rakyat Gabungan Jaksa Pendamai or Justices of Peace \\
PKR & Coalition People's Party \\
PKS & Parti Keadilan National \\
PPRS & Parti Keadilan Rakyat \\
PRM & Parti Kebangsaan Sabah \\
PSM & Parti Perpaduan Rakyat Sabah or Sabah People's Unity Party \\
UMNO & Parti Rakyat Malaysia \\
WARISAN & Parti Sosialis Malaysia or Socialist Party of Malaysia \\
\hline & United Malays National Organization \\
& Parti Warisan Sabah or Sabah Heritage Party \\
\hline &
\end{tabular}




\section{REFERENCES}

Aiman Athirah Al-Jundi. 2006. Srikandi: Mata rantai perjuangan. Selangor: Dewan Muslimat PAS Pusat.

Bauer, M. 1996. The narrative interview: Outline and comments on a technique of qualitative data collection. London: London School of Economics.

Bjarnegård, E. and P. Zetterberg. 2016. Political parties and gender quota implementation: The role of bureaucratized candidate selection procedures. Comparative Politics 48(3): 393-411. https://doi.org/10.5129/001041516818254400

Brooks, A. and S.N. Hesse-Biber. 2007. An invitation to feminist research. In Feminist research practice: A primer, eds. S.N. Hesse-Biber and P.L. Leavy, 1-24. Thousand Oaks, CA: Sage. https://doi.org/10.4135/9781412984270

Cowper-Smith, Y., A. Kopec, T. Sutton and K. Nelson. 2017. Women and politics: Overcoming barriers to participation in leadership. Guelph, ON: Community Engaged Scholarship Institute. https://atrium.lib.uoguelph.ca/xmlui/ handle/10214/8902 (accessed 18 August 2018).

Dancz, V. 1987. Women and party politics in Peninsular Malaysia. Singapore: Oxford University.

Dariko, B., C. Nana, J. Gvantsa and U. Natia. 2017. Sustainable development goal \# 5 gender assessment in Georgia. Georgia: European Union.

Dhar, S. 2018. Gender and sustainable development goals (SDGs). Indian Journal of Gender Studies 25(1): 47-78. https://doi.org/10.1177/0971521517738451

Douglas, L. 2014. Factors impeding political participation and representation of women in Kenya. Humanities and Social Sciences 2(6): 173-181. https://doi.org/10 $.11648 /$ j.hss.20140206.15

Fatima Sbaity, K. 2013. Party politics, religion and women's leadership: Lebanon in comparative. New York: Palgrave Macmillan.

Federal Constitution, Malaysian Law. 2008. Article 8 (2), 2001 Amendment. Selangor: International Law Book Services.

Fox, R.L. and J.L. Lawless. 2014. Reconciling family roles with political ambition: The new normal for women in 21 st century U.S. politics. Journal of Politics 76(2): 398-414. https://doi.org/10.1017/S0022381613001473

Husam Musa. 2013. Ucapan perasmian muktamar tahunan Dewan Muslimat PAS-53. 20 21 November. Selangor: Dewan Muslimat PAS.

Jamilah Ariffin. 1995. Malaysia's attitude towards women's role in society: Findings from a nationwide study. Paper presented at the National Conference on Malaysian Women at the Crossroads of Change, University Malaya, Kuala Lumpur. 7-8 April.

Kassa, S. 2015. Challenges and opportunities of women political participation in Ethiopia. Journal of Global Economy 3:162. https://doi.org/10.4172/2375-4389.1000162

Kementerian Pembangunan Wanita, Keluarga dan Masyarakat (KPWKM). 2016. Statistics on women family and community. Putrajaya: Kementerian Pembangunan Wanita, Keluarga dan Masyarakat.

Kim E.M. 2017. Gender and the sustainable development goals. Global Social Policy 17(2): 239-244. https://doi.org/10.1177/1468018117703444 
Kitzinger, C. 2007. Feminist approach. In Qualitative research practice, eds. C. Seale, D. Silverman, J.F. Gubrium and G. Gobo, 113-128. London: SAGE Publications Ltd.

Lawless, J. 2014. It's the family, stupid? Not quite...how traditional gender roles do not affect women's political ambition. https:/www.brookings.edu/wp-content/ uploads/2016/06/Lawless_GenderRoles.pdf (accessed 15 July 2018).

Maynard, M. 2004. Feminist issues in data analysis. In Handbook of data analysis, ed. A. Bryman, 131-145. London: Sage. https://doi.org/10.4135/9781848608184.n6

Maznah Mohamad. 2001. Women in the UMNO and PAS labyrinth. In Risking Malaysia: Culture, politics and identity, eds. Maznah Mohamad and Wong Soak Koon, 112-118. Selangor: Universiti Kebangsaan Malaysia.

Milbrath, L.W. 1971. Political participation: How and why do people get involved in politics. Chicago: Rand McNally \& Company.

Ministry of Women, Family and Community Development. 2016. Statistic on women, family and community. https://www.kpwkm.gov.my/kpwkm/uploads/files/ Penerbitan/Buku\%20Perangkaan/Perangkaan\%202016.pdf (accessed 13 June 2018).

Munira Abdul Razak. 2004. Women in Malaysian politics: An exploratory study. MA diss., International Islamic University Malaysia, Kuala Lumpur.

Ng, C., Maznah Mohamad and B.H. Tan. 2006. Feminism and the women's movement in Malaysia: An unsung (r) evolution. London and New York: Routledge. https://doi.org/10.4324/9780203099315

O'Neil, T. and P. Domingo. 2015. The power to decide: Women, decision-making and gender equality, https:/www.odi.org/sites/odi.org.uk/files/odi-assets/ publications-opinion-files/9848.pdf (accessed 16 August 2018).

Parliament Malaysia. 2018. Statistik Dewan Rakyat. https:/www.parlimen.gov.my/ statistik.html?uweb=dr\& (accessed 19 August 2018).

Parti Islam SeMalaysia. 2012. Perlembagaan Parti Islam Se-Malaysia, Pindaan 2011 (The Constitution of Parti Islam SeMalaysia, 2011 Amendment). Selangor: Pejabat Agung PAS.

Paxton, P., S. Kunovich and M.M. Hughes. 2007. Gender in politics. The Annual Review of Sociology 33: 263-284. https://doi.org/10.1146/annurev.soc.33.040406.131651

Puwar, N. 1997. Reflections on interviewing women MPs. Sociological Research Online 2(1): 82-91. https://doi.org/10.5153/sro.19

Rashila Ramli. 1998. Pembangunan politik dan gender: Cabaran dan strategi bagi caloncalon wanita. In Gender, budaya dan masyarakat, eds. Rokiah Talib and Shanti Thambiah, 152-162. Kuala Lumpur: Universiti Malaya.

Rudie, I. 1994. Visible women in East Coast Malay Society: On the reproduction of gender in ceremonial. Oxford: Oxford University Press.

Saba Mahmood. 2005. Politics of piety: The Islamic revival and the feminist subject. Princeton, NJ and Oxford: Princeton University Press.

Salbiah Ahmad. 1994. Religion and culture: Prohibitive factors for women's participation in politics. In Malaysian women creating their political awareness, eds. R. Haas and Rahmah Hasyim, 47-48. Kuala Lumpur: Asian Institute for Development.

Schutlz, T.W. 1961. Investing in human capital. American Economic Review 5(1): 1-17 
Sharifah Syahirah Syed Shahabudin and Norfarhanis M.S. 2015. Affirmative policy implementation and women empowerment in Malaysian public sector. Paper presented at the Australasian Conference on Business and Social Sciences, Sydney. 13-14 April.

Seyedeh N., K. Hasnita and A. Hossein. 2010. The financial obstacles of women's political participation in Iran. Report and Opinion 2(10): 41-49.

Tan, Y.K. 1993. Ethnicity, political awareness and participation. Paper presented at Seminar on Creating Political Awareness among Malaysian Women organized by Asian Institute for Development Communication, Kuala Lumpur. 12-14 July.

United Nations. 2016. Sustainable development goals. New York: United Nations. https://sustainabledevelopment.un.org/?menu=1300 (accessed 19 July 2018).

United Nations Statistics Division. 2016. Goal 5 achieve gender equality and empower all women and girls. https://unstats.un.org/sdgs/files/metadata-compilation/ Metadata-Goal-5.pdf (accessed 16 August 2018).

Verba, S., K.L. Scholzman and H. Brady. 1995. Voice and equality: Civic voluntarism in American politics. Cambridge: Harvard University Press.

Wazir Jahan Karim. 1992. Women \& culture: Between Malay adat and Islam. Boulder: Westview Press.

Waylen, G. 2014. A seat at the table - Is it enough? Gender and multiparty negotiations in South Africa and Northern Ireland. Politics \& Gender 10(4): 495-523. https://doi.org/10.1017/S1743923X14000397

World Economic Forum. 2017. Global gender gap report. 2017. http://reports.weforum .org/global-gender-gap-report-2017/ (accessed 20 July 2018).

Zaireeni Azmi. 2001. Gender dan politik: Kajian kes ke atas wanita UMNO dan PAS di Selangor dan Terengganu. MA diss, Universiti Malay, Kuala Lumpur. 2017. Penglibatan politik dan keberadaan wanita PAS di Selangor dan Kelantan (1982-2015). PhD diss, Universiti Kebangsaan Malaysia, Selangor.

Zeenath Kausar. 2006. Women in politics: The case of Peninsular Malaysia. Kuala Lumpur: International Islamic University Research Center. 